\title{
Grzegorz Blicharz, Commons - dobra wspólnie użytkowane. Prawnoporównawcze aspekty korzystania z zasobów wodnych. Bielsko-Biała: Wydawnictwo Od.Nowa, 2017, stron 195
}

\author{
Abstract \\ Grzegorz Blicharz, Commons - Jointly-used Goods: Comparative Aspects of the Use \\ of Water Resources. Bielsko-Biała: Od.Jowa, 2017, 195 Pages
}

\begin{abstract}
"Commons - Jointly-used Goods: Comparative Aspects of the Use of Water Resources" further develops the theory of governing the dwindling resources, based on Professor Elinor Ostrom's economic theory of Commons, and expands on it on legal science. The monograph highlights the increased effectiveness of bottom-up norms in preventing the complete depletion of the endangered resources while simultaneously satisfying the needs of the local community, if the public authorities decide to respect them. The legal and functional characteristics of those norms aren't uniform in different legal traditions, which is shown by examples from various legal systems provided by the author. The author also acknowledges that the issue of property and restricting it in the interests of other people was often mentioned in Roman law, especially in arguments between Roman jurists about water easements. The review describes basic theses and their argumentation contained in the monograph and evaluates its substance, form, and the universal character of the referenced problem.
\end{abstract}

Keywords: jointly-used goods, water resources, bottom-up law, comparative law, Roman law

Słowa kluczowe: dobra wspólnie użytkowane, zasoby wodne, prawo oddolnie tworzone, prawo porównawcze, prawo rzymskie

Doktor Grzegorz Blicharz w swojej monografii Commons - dobra wspólnie użytkowane. Prawnoporównawcze aspekty korzystania z zasobów wodnych pochyla się nad koncepcją dobra wspólnego, czyli zasobów naturalnych będących własnością wszystkich ludzi. Jest ona ugruntowana nie tylko w biblijnej wizji świata, lecz również w fundamencie europejskiej tradycji prawnej, czyli prawie rzymskim. Potwierdzone zostało to w Drugiej 
Księdze Instytucji Gaiusa: „I są takie dobra, które wedle prawa naturalnego są wspólne wszystkim: powietrze, woda płynąca i morze i z tego powodu brzegi tego morza. Nikomu zatem nie można zabronić dostępu do tego morza, jeśli zachowa znajdujące się tam domy, pomniki, budynki, które przecież nie podlegają prawu narodów, tak jak morze" (Instit. 2,1;1)1, co zostało przytoczone przez autora (s. 129-130). Poza powietrzem więc to właśnie woda, jako niezbędny element przetrwania, jest uznana za dobro, do którego człowiek ma przyrodzone prawo. We współczesnej nauce podana koncepcja została obszernie opracowana przez Elinor Ostrom (w czym niemały wkład miał jej mąż Vincent Ostrom). Ta profesor ekonomii politycznej i laureatka nagrody Nobla w książce Dysponowanie wspólnymi zasobami (Governing the commons), poza aspektami ekonomicznymi porusza również kwestie prawne zarządzania dobrami wspólnymi. Działalność profesor Ostrom (szerzej rozpropagowana w Polsce dzięki wywiadowi przeprowadzonemu z nią przez prof. Małgorzatę Korzycką na łamach „Forum Prawniczego"”2), jako główna inspiracja przedmiotowej publikacji, niewątpliwie wpłynęła na decyzję autora, by pochylić się nad zasobami wspólnymi nie tylko od strony normatywnej, ale również z perspektywy ekonomicznej. Poniższe opracowanie jest pobieżnym opisem podstawowych założeń, na których opiera się publikacja Grzegorza Blicharza.

Główną tezą publikacji jest, że w przypadku zagrożenia wyczerpania zasobów wspólnych odgórna inicjatywa prawodawcza (top-down) jest znacznie mniej efektywna w ochronie dóbr niż oddolne tworzenie norm postępowania przez lokalne wspólnoty (bottom-up), które wymagają jedynie uszanowania władz publicznych. Jest to swoiste odejście od systemu prawa stanowionego na rzecz stanowiska kazuistycznego, które nie tworzy uniwersalnych zasad postępowania i abstrakcyjnych unormowań prawnych. Z perspektywy ekonomicznej jest to koncepcja zupełnie odwrotna do popularnego przekonania, że to człowiek zagraża środowisku naturalnemu, gdyż dąży do ciągłej maksymalizacji swojego zysku, przez co państwo musi kontrolować jego działalność. Z perspektywy prawnej zaś prawo tworzone przez wspólnoty może wchodzić w kolizję z prawem stanowionym, co doprowadziłoby do konfliktu, w którym państwo miałoby o wiele silniejszą pozycję. Poza tym system prawa tworzonego przez lokalne społeczności nie ma skutecznego mechanizmu sankcjonowania naruszeń wypracowanych we wspólnocie reguł, a zewnętrzna kontrola zachowań przez niezależnych arbitrów mogłaby być zbyt kosztowna dla lokalnej grupy mieszkańców. Zastanawiająca jest również struktura właścicielska tychże dóbr.

Praktyka i skuteczne korzystanie z zasad oddolnego tworzenia norm prawnych wychodzą jednak naprzeciw tym zarzutom i pokazują, jak rzeczywiste rozwiązania, przy zaangażowaniu samych zainteresowanych, mogą funkcjonować nie tylko bez wskazanych powyżej wad, ale również skuteczniej niż w przypadku nacjonalizacji bądź prywatyzacji zagrożonego zasobu. Dobrym przykładem podanym przez autora monografii, jest wspólnota rybaków w Alanyi w Turcji (s. 64-66). Z powodu znacznego pogorszenia się ich sytuacji ekonomicznej w latach 70 . XX w. rybacy musieli odejść od praktyki rywalizacji i wyścigu po zasoby wspólne, jakim były łowiska ryb. Zamiast tego wypracowali porozumienie, w którym ustalili łagodne zasady połowu ryb z podziałem na strefy,

1 Gaius. Instytucye Gaja, Ks. 2. Tłum. Teodor Dydyński. Warszawa: Księgarnia H. Natansona, 1865.

2 Forum Prawnicze 1 (wrzesień 2010): 5-11. 
tak aby nikt nie wchodził w drogę innym. Nie można więc uznać za bezsprzeczne, że człowiek zawsze dąży do zwiększenia swoich korzyści, gdyż w tym przypadku maksymalizacja zysków nie jest głównym priorytetem. Gdyby nim była, to współpraca stałaby się niemożliwa, a ochrona wspólnego zasobu - nieskuteczna. Argumenty zarzucające nieefektywność tymże rozwiązaniom z perspektywy prawnej również mogą być podważone dzięki temu przykładowi. Porozumienie między rybakami jest potwierdzane przez lokalnego urzędnika, który akceptuje porządek prawny wspólnoty. Władza centralna Turcji nie wkracza w kompetencje urzędu lokalnego, co sprawia, że nie dochodzi do kolizji norm obu systemów. Ponadto kontrola zachowań i naruszeń odbywa się samoczynnie - sami zainteresowani sprawdzają, czy pozostali członkowie wspólnoty wykonują postanowienia porozumienia, gdyż jest to $\mathrm{w}$ ich interesie. Za to system stosowania sankcji został przedstawiony na porównywalnym przykładzie wspólnoty rybaków z Nowej Szkocji (s. 42-45). W takim systemie sankcją jest np. zagrożenie pocięciem sieci przez członków wspólnoty, co daje większy posłuch wobec prawa niż państwowe regulacje.

Skuteczne stworzenie systemu korzystania z dóbr wspólnych może, w opinii autora przedmiotowej monografii, potencjalnie naprawić wiele problemów w dzisiejszym prawie: brak elastyczności oraz brak zaufania do prawa i sądów. Pierwszy z problemów jest rozwiązywany przez łatwość w zmianie norm postępowań w porównaniu z prawem stanowionym - w przypadku wspólnoty rybaków z Alanyi porozumienie było spisywane na nowo corocznie, w wielu zaś innych przypadkach większość norm jest w pełni ustna i może być modyfikowana w zależności od wymagań sytuacji. Drugi problem mieści się $\mathrm{w}$ nadprodukcji norm prawnych oraz wysokich kosztach sądowych przy długich okresach oczekiwania na wyrok. Rozwiązaniem jest specjalnie tworzone sądownictwo, złożone w pełni z przedstawicieli wspólnoty bądź połączonych wspólnot. Najlepszym przykładem jest Trybunał Wodny w Walencji, który funkcjonuje autonomicznie od XIV w., rozstrzygając spory między członkami wspólnot wokół ośmiu kanałów irygacyjnych wschodniej Hiszpanii (s. 100-109). Kierując się przede wszystkim dobrem wspólnoty, nie orzeka według często skomplikowanego prawa powszechnego, tylko według zwyczaju i wielowiekowej tradycji. Postępowanie sądowe odbywa się bez prawników, z koncentracją materiału dowodowego, a jego rozstrzygnięcie podawane jest na tej samej rozprawie (do niedawna w pełni ustnej formie), co powoduje, że jest ono szybsze i bardziej ekonomicznie opłacalne od zwykłej drogi sądowej. Pod wieloma względami jest podobne do alternatywnych metod rozstrzygania sporów (ADR), z tą różnicą, że postanowienia Trybunału są w pełni respektowane przez prawo stanowione. $Z$ drugiej strony, przez ustność postępowania i skuteczność orzeczeń wynikającą przede wszystkim z autorytetu (auctoritas), instytucja ta upodabnia się do sądownictwa starożytnego (np. sądy centumwiralne, greckie trybunały ludowe).

W monografii podkreślony został unikatowy charakter zarządzania commons z perspektywy prawa rzeczowego. Każda wspólnota, z powodu różnic kulturalnych i geograficznych oraz zależnie od charakteru zagrożonego dobra, tworzy własne regulacje w tym aspekcie. Wspólnota rodzin w Nepalu inwestująca w budowę kanału irygacyjnego wprowadziła jego podzieloną własność prywatną proporcjonalną na wzór rzymskiej societas do wkładu w jego budowę (s. 63). Mieszkańcy południowoszwajcarskiej wioski łączą własność prywatną rodzinnych nieruchomości z własnością wspólną łąk do wypasu zwierząt hodowlanych, tworząc wspólnotę, która z jednej strony jest podobna 
do dzisiejszej spółki, gdyż jest traktowana jako pojedynczy podmiot obrotu prawnego, z drugiej strony, na wzór rzymskiej societas, przy zmianach osobowych potrzeba na nowo zawrzeć porozumienie (s. 66-68). Jest też model zanjeras - filipińskich wspólnot, które, na wzór emfiteuzy, pozwalają nie-właścicielom ziemi nawadniać ją i uprawiać w zamian za przekazywanie części plonów właścicielowi (s. 61-63). Jak wynika z podanych wyżej przykładów, istnienie praw właścicielskich nie wyklucza istnienia praw wspólnotowych, przez co mogą się one nawzajem dopełniać w ochronie wspólnego dobra.

Co jednak, jeśli ochrona dobra wspólnego wymaga ograniczenia prawa własności nawet bez zgody właściciela? Ograniczeniu praw właściciela zdecydowanie sprzeciwia się najbardziej klasyczna definicja własności wypracowana przez znanego koncyliatora Bartolusa de Saxoferrato, którą można nazwać negatywną definicją własności: „prawo do rozporządzania rzeczą materialną, którego ustawa nie zabrania" (s. 85)3. W drugiej połowie XIX w. powstała jednak inna teoria Léona Duguita. Według niej własność rzeczy była związana nie tylko z prawami, ale również z obowiązkami wobec innych. Właśnie spór między tymi koncepcjami był zarzewiem opisanego przez autora monografii konfliktu w sprawach przed kalifornijskimi sądami słuszności (equity courts) dotyczących zasad pobierania wód gruntowych (s. 112-114, 137-141). Zgodnie z przełomowym wyrokiem Sądu Najwyższego Kalifornii City of Pasadena vs. City of Alhambra potwierdzone zostało porozumienie wspólnoty, w którym to właściciele wody na podstawie praw gruntowych (overlying rights)i osoby, które zasiedziały swoje prawa do wody (prescriptive rights), zostali zrównani wprawach do pobierania wód gruntowych $\mathrm{z}$ osobami, które nie miały żadnych praw rzeczowych poza przywłaszczonymi (apropriative rights). Takie „wzajemne zasiedzenie” odbyło jednak się kosztem właścicieli gruntów, którzy musieli zmniejszyć swoje pobieranie wody do racjonalnego poziomu, nawet jeśli nie zgadzali się z treścią zawartego porozumienia. Precedens Pasadeny wywołał szereg kontrowersji i był z czasem ograniczany przez następne wyroki na rzecz właścicieli i podmiotów publicznych, ale jednocześnie rozpoczął ważną debatę dla ochrony zasobu wspólnie użytkowanego.

Spór ten, choć wydawać się może współczesny w swojej naturze prawnej, znany był, co zaznacza autor monografii, prawu rzymskiemu i rzymskim jurystom. Można mówić tutaj o swoistym „sporze pokoleniowym” między starszym jurystą, Labeonem, a młodszym, Prokulusem. Pierwszy z nich uznawał, że wodę z własnego wodociągu można udostępniać komukolwiek, mimo iż nie wynikało to ze służebności gruntowej. Prokulus zaś sprzeciwiał się temu poglądowi, twierdząc, że wody z wodociągu nie można nawet odprowadzić na inną część swojego gruntu, poza tą, na której była służebność. Pomponiusz, po przywołaniu opinii obu jurystów ${ }^{4}$, zgadza się z Prokulusem. Zarówno jednak opinia Prokulusa, jak i opinia Labeona cieszyły się poparciem w rzymskim porządku prawnym, a odzwierciedlenia tych poglądów można zaobserwować w sporach o commons. Precedens w sprawie Pasadena jest porównywalny do zdania Labeona, zaś następne wyroki ograniczające ten precedens - podobne są do zdania Prokulusa. Potwierdza to jedynie uniwersalność problemów w rzymskim ius controversum, jak rów-

3 Quid ergo est dominium? Responde, est ius de re corporali perfecta disponendi, nisi lege prohibeatur.

4 D. 8,3,24. Pomponiusz, ks. 33 „Komentarza do dzieł Sabinusa” (s. 153 książki). 
nież podkreśla użyteczność prawa rzymskiego jako siatki pojęciowej dla współczesnych problemów prawnych.

Przedmiotowa publikacja napisana została językiem zrozumiałym i precyzyjnym, niepozostawiającym wątpliwości co do istoty omawianego zagadnienia, ale przede wszystkim przemawiającym także do młodych adeptów prawa. Obszerny wybór przykładów z całego świata pozwala na skuteczne zaprezentowanie wielu skomplikowanych rozwiązań w praktyce i uplastycznienie potencjalnie hermetycznych zagadnień prawnych. Ponadto poszerza to spektrum zwykłego ujęcia dogmatycznego, które jest dominujące w wielu opracowaniach dzisiejszej doktryny. Szeroki wachlarz źródeł naukowych, zarówno prawniczych, jak i innych, jest potwierdzeniem wielowymiarowości pracy, a lekkość w przytaczaniu zagranicznych regulacji w oryginale wraz z thumaczeniami świadczy o erudycji autora oraz dbałości o detale. Podejście komparatystyczne całej monografii, skupione na prawie rzymskim, przedstawia perspektywę prawnohistoryczną, której nie można przecenić w dzisiejszej nauce prawa. Najważniejszy jest jednak fakt, że omawiana monografia jest oryginalnym opracowaniem doniosłego tematu commons pod względem prawnym, który teraz bardziej niż kiedykolwiek wcześniej wart jest dogłębnego przeanalizowania.

Omawiane zagadnienie jest wartościowym przedmiotem badań prawnych pod względem prawa rzeczowego, gdyż w dynamicznie zmieniającej się rzeczywistości dzisiejszego świata możemy zaobserwować rosnącą popularność korzystania z cudzych dóbr z niemal identycznymi uprawnieniami z tymi, jakie posiada właściciel, w postaci np. leasingu, time-sharingu, licencji na oprogramowanie i wielu innych. Rozwój prawa rzeczowego commons przekłada się zaś na usprawnienie systemów praw ochrony środowiska oraz praw własności intelektualnej. Zwykli użytkownicy takich dóbr, jak internet lub media społecznościowe cieszą się coraz większymi uprawnieniami, wobec których ograniczenia właścicielskie spotykają się z szeroko zakrojonym oporem. Wielu poszerza zbiór dóbr wspólnych i cywilizacyjnych praw człowieka na prawo do czystego środowiska lub do pokoju i bezpieczeństwa. Potwierdza to potrzebę dalszego badania i zrozumienia istoty commons w celu utworzenia skuteczniejszych systemów społecznych i prawnych, opartych na ochronie wspólnej własności wszystkich ludzi. 